\begin{tabular}{l|l}
\hline Notaice & e-ISSN: 2655-9404 \\
Vol. 2 No. 2, Juni 2019 & DOI: $10.20473 /$ ntr.v2i2.13174 \\
\hline
\end{tabular}

Article history: Submitted 9 May 2019; Accepted 23 May 2019; Available online 1 June 2019.

\title{
Automatic Exchange of Information on Indonesia Jurisdiction in order to Control Business Opportunities
}

\author{
Adrian Adhitana Tedja, Vincent Arta Wijaya, and Jevelyn Lidyawati \\ adrian.adhitana@gmail.com \\ Universitas Airlangga
}

\begin{abstract}
The Automatic Exchange of Information (AEOI) is a product of common reporting standard as a result of Indonesia's ratification of the Convention on Mutual Administrative Assistance in Tax Matters. The convention purpose is to prevent transnational tax evasion and money laudry, with the existence of an automatic exchange of information system through out members of the convention can enact and enforce its laws. The main problems concerning an autamated system is the jurisdiction regarding the enacting state, as well as bank secrecy laws in ratifying countries. With banks are compromised to reveal tax payers information to the state, many tax payers will eventually lose interest in one state and start seeking tax havens, which will impact the economy and business sectors as well as trade policies between states. The purpose of this research is to find out what law governs AEOI in Indonesia and its impact on transnational jurisdiction between ratifying and non-ratifying states. This research is a juridical-emphirical research which uses statute approach, conceptual approach and comparative approach. The research compares Indonesia laws including banking law as well as statistics of Indonesian economic growth since the enactment of tax amnesty as a reaction towards AEOI. The conclusion of this research is that jurisdiction regarding AEOI is already being settled through bilateral and multilateral treaties to be implemented in their national laws, however Indonesia's bank secrecy law need to be adjusted to the new AEOI provisions in order to compliment tax enforment.
\end{abstract}

Keywords: Information; Tax Evasion; Money Laundry; Jurisdiction.

\section{Introduction}

People's welfare is the goal of every country. No exception for the Republic of Indonesia in accordance with Article 33 paragraph (1) of the 1945 Constitution of the Republic of Indonesia which reads «The economy is prepared as a joint effort based on the principle of family» and Article 33 paragraph (3) of the 1945 Constitution of the Republic of Indonesia which reads «Earth, water, and all the wealth contained in it is controlled by the state and used for the prosperity of the people «. From the above article it can be seen that the natural resources in a country are important so they must be controlled by those who against the prosperity of the people.

In its efforts to achieve people's welfare, the State must be careful in carrying out important development projects, because in the present time there are cases that are detrimental to the country's economy such as abuse of authority, embezzlement 
and tax evasion. Misuse of authority as and example of those detrimental to state funds has been regulated in Act number 20 year 2001 concerning Amendments to Act number 31 year 1999 concerning Eradication of Corruption Crimes and Act number 30 year 2014 on Government Administration. Article 3 of the Eradication of Corruption Crimes Act reads «Anyone who aims to benefit himself or another person or a corporation, misusing authority, opportunity or facilities available to him because of a position or standing that could harm the state's finances or the country's economy, sentenced to a life imprisonment or imprisonment of at least 1 (one) year and a maximum of 20 (twenty) years and or a fine of at least Rp. 50,000,000.00 (fifty million rupiah) and a maximum of Rp. 1,000,000,000.00 (one billion rupiah) «. Criminal actions that violate the Act are categorized as acts of corruption. The Indonesian state also created an independent institution that specifically deals with corruption crime according to Act number 30 year 2002 concerning the Corruption Eradication Commission (Komisi Pemberantasan Korupsi) called the KPK. Article 6 paragraph (2) letter a of the Administrative Government Act stipulated that government official actions must be done in accordance to the law and good governance principles. These limitation are created to enforce and protect state funds from being misused.

Responding to the State's efforts to eradicate corruption, corruptors react by opening a bank account abroad such as in Switzerland. The account information thus cannot be accessed by the Indonesian State so that it cannot be tracked or taxed. This gap is widely used by businessman in Indonesia to hide their assets in order to avoid taxes. This action is very detrimental to state funds as trillions of Rupiahs which should be used for public policies and development are used in other countries.

Facing peoples who are detrimental as aforementioned, the state decides to follow the system of exchanging taxpayers' information between countries called Automatic Exchange of Information (hereinafter it's called AEOI). AEOI is a system that supports the exchange of information between taxpayers between countries at a certain time periodically, systematically, and continuously from 
the state of the source of income or a place to store wealth, to the taxpayer resident state. ${ }^{1}$ Through this AEOI system, it is hoped that in addition to achieving financial transparency, the state can also maximize development for the welfare of the people.

\section{Laws regarding tax and information on taxes}

Tax are essential to part of a society and especially to a country. As Benjamin Franklin said, there are only two things which are certain in this world, which is : death, and taxes. ${ }^{2}$ Since taxes are so fundamental in a country ability to survive, therefore it must be enforced upon its people. The famous quote on taxes also comes from the founding fathers of today United States of America, which is "No taxation without representation". This quote meant that taxation must be regulated by the people's representative. People's Representative of a country must create laws which will be the legal basis for a country to collect taxes from its people. This is why tax law are important in a country to enforce its collection and obtain an amount of tax for the country's budgeting purposes.

Before going to the regulation regarding taxes, there are some definition from scholars on what is tax. Prof. Edwin R.A. Seligman in his Essays in Taxation (New York 1925), stated that "Tax is a compulsery contribution from the person, to the government to defray the expenses incurred in the common interest of all, without reference to special benefit conferred". ${ }^{3}$ Louis Kaplow define tax as a method and system of the retribution of wealth potentially required for social utility maximization. ${ }^{4}$ From the definition regarding taxes, tax main purpose is:

\footnotetext{
${ }^{1}$ Finansialku.com, 'Bagaimana Kabar Kelanjutan Setelah Amnesti Pajak Yang Sudah Berakhir?' (Finansialku.com, 2017) < https://www.finansialku.com/setelah-amnesti-pajak-berakhir-kehadiran-aeoi-automatic-exchange-information-di-indonesia/> accessed 10 August 2018.

${ }^{2}$ Smyth dan Albert Henry, The Writings of Benjamin Franklin, Vol. X (1789-1790) (MacMillian 1907).[69].

${ }^{3}$ R.Santoso Brotodihardjo, Pengantar Ilmu Hukum Pajak (Refika Aditama 2013).[4].

${ }^{4}$ Boudewijn Bouckaert dan Gerrit De Geest, 'Economics of Public and Tax Law' (2000) 4 Encyclopedia of Law and Economics.[715].
} 
1. budgeting function;

2. social function; and

3. control function.

Its budgeting function refer to the ability to provide state budget. The state collect money from the people and redistributing them as state funds to be converted to be used by the government in state activities. Its social function is as a result of the budgeting function, which is the government has the responsibility to redistribute the money collected from the people to be various public facilities and public interest. The last is control function, which is used to control certain activities conducted by individuals within a country. The government may impose greater tax to products which are not encourage or are trying to be limited by the government, an example is tax on cigarettes and on fossil fuel vehicles.

Legislation in Indonesia which regulates on matter of tax is based on Act number 6 year 1983 which have been amended for the last time by Act number 16 year 2009 on General Regulation and Procedure on Taxation. The law which have been amended numerous times have regulated mainly on tax paying mechanism and also authority given to the government to collect tax from tax-payers. However from article 29 stated about the mechanism for the government to inspect the compliance of the tax payers and the amount of which should be deposited by the people to the government. The system of inspecting closely relates to either administrative laws which covers the authority and procedure of tax collecting and also criminal law.

Criminal law is still a important aspect in upholding laws against crimes of taxation. There are 3 (three) kinds of resistance against tax, ${ }^{5}$ which are :

1. tax avoidance, tax avoidance is the act of a tax-payer to not pay tax by means which either done or not be done so that the authorized official may not be able to impose or collect the tax that can be obtained from the tax-payers. This action is not against the law, however it reduces the amount of tax that should be able to be collected if tax avoidance did not occur.

\footnotetext{
${ }^{5}$ R.Santoso Brotodihardjo (n 3)., Op.Cit.[14-20].
} 
2. tax evasion, different with tax avoidance, tax avoidance can get away by the fact that the tax is not impose by the action or choices that tax payers do in order to avoid being collected. In contrary, if a tax-payers did not avoid to be collected, but do means which hides the fact or gives false information of the object which should be imposed tax differently, therefore its a tax evasion. Tax evasion are strictly prohibited by the law and can be imposed criminal sanctions against its offenders.

3. tax resistance, tax-payers who refuses to pay taxes or amount of taxes which are regulated by the government conduct tax resistance. Tax resistance is the act of refusing to pay tax even when tax are being collected. In laws regarding tax there are provisions which regulates force collection or by seizure towards tax payers who refuses to pay tax.

The Automatic Exchange of Information (AOEI) is also a form of law that regards to the prevention and method to decrease the amount of tax avoidance as well as tax evasion. Although some scholars disagree with criminal sanction imposed on tax wrongdoings, such as tax evasion and tax avoidance because tax are essentially the money of the people, therefore the people can not be charged guilty for not distributing their money for themselves, however for public interest, tax law are also classified as public law. A study in the history of tax evasion and avoidance in Israel in the 1950s and 1960s show that the willingness of judges in the jurisdiction to impose jail punishment to perpetrators of tax evasion showed a decrease in the amount of tax evasion. ${ }^{6}$ From the studies show the important of tax law enforcement and legislation to the conformity of tax-payers obedience with the law and their cooperation with the authorized government who collect taxes.

As does national country needs to enforce its tax-payers to pay their taxes in their own jurisdiction. Unfortunately, due to globalization and increasingly popular global demand for foreign investments, many tax avoidance and/or tax evasion practices happen by transferring tax objects to overseas where the law are more relaxed, earning themselves the name tax-havens. The European Union

6 Assaf Likhovski, 'Formalism and Israeli Anti-Avoidance Doctrine in the 1950s and 1960s' (2004) 1 John Tiley-Studies in the History of Tax Law.[373]. 
have blacklisted 17 countries which are considered tax havens after a 10 month investigation, these countries include : American Samoa, Bahrain, Barbados, Grenada, Guam, South Korea, Macau, Marshall Islands, Mongolia, Namibia, Palau, Panama, Saint Lucia, Samoa, Trinidad and Tobago, Tunisia and the United Arab Emirates. ${ }^{7}$ International law also played a role in the enforcement of antitax avoidance and evasion. Through these considerations, the Organization for Economic Co-operation and Development (OECD) have international treaties concerning international tax laws. There are also bilateral treaties made by each countries, but the most important recently is the Global Forum on Transparency of Information on Tax Purposes (Global Forum) which is participated by 139 countries or jurisdiction including Indonesia. ${ }^{8}$ The Global Forum discuss anti avoidance system implemented in each jurisdiction to allow for an automated and transparent

\section{International tax law and its jurisdiction}

The effects on globalization on the development of tax law creates a crucial role in international law. The development of tax law means that not only administrative law and criminal law that correlates, but also international law. In most cases, laws in one country jurisdiction also regulates income taxes from their tax-payers which lives or work overseas. For example in Article 1 number 22 of Act number 6 year 1983 which have been amended by Act number 16 year 2009, stated that tax credit includes tax which are credited in overseas are also a subject of national tax in Indonesia.

The basis of international law on tax are similar to international law in general. The main source of international law is based on treaties, either bilateral or multilateral. The second most common source of law is customary law. In the sense of tax, the main theory of taxation should be applied in international tax law, however with different customary laws between countries, there should be a

\footnotetext{
${ }^{7}$ Independent, 'EU Creates Blacklist of 17 Tax Heaven Countries' (Independent, 2017) $<$ https://www.independent.co.uk/news/business/news/eu-tax-haven-offshore-avoidance-countriesblacklist-latest-a8092826.html> accessed 1 April 2019.

${ }^{8}$ Explanation of Lieu of Law number 1 year 2017 on Acess to Finance Information for Taxation Purposes (The Republic of Indonesia State Gazette Year 2017 Number 95 Annotation 6051).
} 
uniformed legislation concerning tax. The uniformed law should be applied as a standard for each countries legislation to adjust accordingly. The fact that tax laws in various jurisdiction actually interact with each other, and one can document cases of direct influence. ${ }^{9}$ The direct influence in taxes across jurisdiction can be regulated and agreed upon to create one single law regarding international tax.

The uniformed law is created by the OECD, an international organization which focuses on economic growth and development, in itself tax is an important aspect for a state's economy. To increase the effectiveness of a country to collect tax and increase the economic growth, the OECD encourage countries to increase its tax income. On international level it is increasingly important for countries to adopt international law standards in its own jurisdiction. The products created by the OECD which is concentrated on international taxation which is adopted by most countries is the Convention on Mutual Administrative Assistance on Tax Matters, which have been participated by 125 jurisdiction including OECD member states and non member states. ${ }^{10}$ The amount of countries which adopted the convention make the convention universally adopted by countries which tries to avoid being called tax havens, which may cause problems regarding political circumstances with other countries. Jurisdiction like the European Union or the UK may impose sanctions or cut off bilateral cooperation which is essential in a countries development of economic growth, which is why most countries obey the convention and its products.

One of the products which leads directly to the AEOI is the Global Forum, which is initiated by G20 countries, which based the standards of AEOI based on the United States Foreign Account Taxpayers Compliance Act (FATCA). ${ }^{11}$ As stated under Article 4 of the Convention on Mutual Administrative Assistance on

\footnotetext{
9 Reuven S. Avi Yonah, International Tax as International Law : An Analysis of the International Tax Regime (Cambridge University Press 2007)[3].

${ }^{10}$ OECD, 'Convention on Mutual Administrative Assistance in Tax Matters' (OECD, 2019) $<$ http://www.oecd.org/ctp/exchange-of-tax-information/convention-on-mutual-administrative-assistance-in-tax-matters.htm> accessed 18 August 2018.

11 ibid.
} 
Tax Matters, the party of the convention shall exchange information related on tax matters. Prior to the Global Forum, tax information between states are obtained via request. The method of exchange of information on request creates problem of efficiency and cost. The country requesting the information must go to length where requesting information to another country is deemed too costly to be conducted on regular basis. Which is why the convention also provide a form of automatic exchange of information between states provided under Article 6 of the convention.

The problem regarding an automated exchange of information is the existence of bank secrecy laws. The idea of an automatic exchange of information comes from the United States FATCA, where the US did not specify clearly in their laws regarding bank secrecy, this is different with Swiss Banks which offers absolute secrecy for sometime. ${ }^{12}$ As the most well known pioneers of bank secrecy, the Swiss uphold their bank secrecy from the root of their neutrality in politics. The establishment of their banking law in 1934 mark the first bank secrecy regulation in the world which becomes one of the trademark of Swiss banks and their popularity among the world, not limited to wealthy overseas businessmen, politician and catholic priest who need to save their assets from unwanted attention.

In Indonesia, bank secrecy laws are not absolute as it is in Switzerland, however the existence of a secrecy in banking also have an impact in the effort of an automatic exchange of Information. The first problem that should be answered in determining the urgency or an automatic exchange of information should be seen from the history of crimes related to money laundry. The effectiveness of anti-money laundering regulation, and therefore the greater impermeability of the banking financial system, depends on the first of the key feature : information. ${ }^{13}$ Information plays a key factor in preventing as well as counter-act any form of criminal activity and unlawful acts in the business and banking sectors. Which is why the development of bank secrecy has changed in the last century concerning

\footnotetext{
12 R.Santoso Brotodihardjo (n 3).Op.Cit.[58].

13 Donato Masciandaro dan Olga Balakina, Banking Secrecy and Global Finance: Economic and Political Issues (Palgrave Macmillan 2015).[100].
} 
the more prominent act of money laundering which causes tax evasion in many jurisdiction around the world. The effect highly degrade the amount of tax that the government of states can collect and reduce their capability to increase development. In these circumstances, the necessity of an automatic exchange of information between states are in dire need.

The global forum which Indonesia been partially-compliant, in itself is adopted in Indonesia's national law in the form of a number of regulations. The most prominent is the Lieu of Law number 1 year 2017. Indonesia is pressured by members of the forum to adopt the automatic exchange of information within its territory as a compliance to the treaty. The president saw the pressure as an emergency situation which based on the Indonesian Constitution the only reason for the president to enact a lieu of law. Before 2017, the government, through its ministry of finance, enacted tax amnesty programs in 2016 through Act number 1 year 2016. It is then being continued by the minister of finance, Sri Mulyani, with the minister of finance regulation number $118 / 2016$. The aim of the tax amnesty is to give taxpayers a chance to withdraw their money from tax-havens overseas and to be put in the fold as tax in Indonesia. Before the automatic exchange of information taken place, the tax-payers must withdraw their money or else the system will be able to detect any tax avoidance or evasion especially income tax that are placed in banks or other financial institution which have treaties and cooperation with Indonesia. With the enactment of Act number 9 year 2017, Indonesia officially adopted the automatic exchange of information standard into their jurisdiction.

The problem of contradicting laws within the AEOI Act and banking law is not yet solved. Indonesia banking law is regulated under Act number 10 year 1998 on banking. Article 40 of the law states that the bank need to keep the confidentiality of its customers information, with some exceptions. One of the exception is Article 41 of the law which stated that for the interest of taxation, the head of the central bank needs to give its recommendation to the ministry of finance which will then have the authority to ask the requested bank to reveal the information which is being requested. This mechanism stated in the banking law refers to exchange of 
information by request. It is contradictory to the AEOI system requested by the Global Forum. The authority given to tax collectors in automatic exchange of information is regulated under Act number 9 year 2017. With the same level of legal products, to determine the law which prevail, the basic principle of lex speciali derogat legi generali must be used in determining which law should be used in these circumstances. Generally the law on bank secrecy on banking law is to wide and general to be used in todays need for an efficient system of anti-avoidance and evasion regarding to taxation.

However the law should gives certainty in the case of the procedure of collecting information in banks. Banks are institutions which based themselves on trust and one of the pillars of economy in a country. With a ambiguous regulation, banks and its customers will have a hard time determining which administrative compliance they should take in solving the information issue. Banks will not generously and willingly spread their customer's information if the regulation regarding the topic is still not clear. And the customers will lose trust in banks if they feel that the banks are not trustworthy in keeping both their money and the information regarding it safe and secure.

\section{Effects of enactment of AEOI towards business in Indonesia}

Continuing the trend from banking sectors related to taxes and its infromation, banks are crucial in developing a country's economy. As one of the pillars of economy it is important to determine the health and stability of a bank in regards to the economic growth. Out of the circumstances, high inflation acts like tax on actual balance or banking resources and if at least, a part of this tax is transferred to the deposit of depositors, inflation will lead to the low efficiency in banking deposits and since, the banking deposits compete with kinds of assets, so, reduction in actual interest of banking deposits leads to reduce the actual interest of those assets. ${ }^{14}$ The

\footnotetext{
${ }^{14}$ Parvaneh Kamali Dehkordi dan Abotaleb Kazemi Davood Farhadi Sartangi, 'Review of The Impact Of Inflation Uncertainty On The Financial Development Of Banking Sector (Case Study: D8)' 6 Astra Salvensis.[195].
} 
fear of information from banks leaking to the ears of tax collectors may effect the outcome of business sectors if banking sectors loses its trust-worthiness. However at this time, through the chances given by the government with tax amnesty gives opportunity and gives benefit to tax-payers.

The effects of tax amnesty is regarded successful, because: ${ }^{15}$

1. Increase economic growth up to $5.3 \%$ in 2016 and $5.1 \%$ in 2017 ;

2. Increase funds gain from abroad which enters Indonesia, thus increasing foreign exchange as well as strengthen Indonesia currency. Data from the Central Bank of Indonesia recorded September 2016 as much as US\$ 115.7 billion, hidher than August which is only US\$ 113.5 billion;

3. Gives positive effects on Indonesia Stock Exchange. The Indonesian Stock Exchange stated that there are tens of companies going public. The amount of fund obtained by tax amnesty push the Indonesian Stock Exchange to gain interest from stakeholders use the opportunity to make state-owned companies and regional state-owned companies to go public as well;

4. Gives positive impact on manufacture, property and investments;

5. Indonesian Statistic Board recorded in September inflation is on $0.22 \%$, thus inflation from January to September is $1.97 \%$, where from year to year, annually inflation reaching 3.07\%.

From the progress gained by tax amnesty as a indirect result of the planned AEOI in 2016 and 2017, the amount of funds collected from tax-payers have significantly increased, even though the amount of funds collected from tax amnesty is less than that which is targeted by the government. The positive result from 2016 and 2017 gives promise that in the years to come, the government should focus on law enforcement and supervision through the newly adopted law. Effectively Indonesia have come to the conclusion which it has joined other nations in combating tax avoidance and tax evasion by increasing its tax income and increasing the compliance of its tax payers. From the number 102 jurisdiction participating in AEOI, the hopes of an increasing public facilities and public policy will lead to the increasing number of economic growth.

\footnotetext{
${ }^{15}$ Yuwita Ariessa Pravasanti, 'Dampak Kebijaksanaan Dan Keberhasilan Tax Amnesty Bagi Perekonomian Indonesia’ (2018) 16 Jurnal Ilmiah Akutansi.[91-92].
} 


\section{Conclusion}

The system implemented internationally have the purpose to increase the effectiveness of tax collection and its utilization around the world. The jurisdiction which AEOI is being used are also regarded as one effort for international tax compliance and decreasing the amount of tax havens in the world. Laws regarding international tax laws and jurisdiction problems are already being settled by multinational treaties such as the Convention on Mutual Administrative Assistance on Tax Matters, as well as bilateral treaties between states which are party to the Global Forum in order to excecute the AEOI system. AEOI is a joint effort between several jurisdiction and Indonesia is no exception to provide and aid other countries in erradicating and minimalizing tax evasion. The problem with Indonesia tax laws is that the banking law regarding bank secrecy must be adjusted with the new AEOI system. Laws should be changed in order to accomodate and create legal certainty regarding AEOI.

\section{Bibliography}

\section{Books}

Donato Masciandaro dan Olga Balakina, Banking Secrecy and Global Finance: Economic and Political Issues (Palgrave Macmillan 2015)

R.Santoso Brotodihardjo, Pengantar Ilmu Hukum Pajak (Refika Aditama 2013)

Reuven S. Avi Yonah, International Tax as International Law: An Analysis of the International Tax Regime (Cambridge University Press 2007)

Smyth dan Albert Henry, The Writings of Benjamin Franklin, Vol. X (1789-1790) (MacMillian 1907)

\section{Journal}

Assaf Likhovski, 'Formalism and Israeli Anti-Avoidance Doctrine in the 1950s and 1960s' (2004) 1 John Tiley-Studies in the History of Tax Law

Boudewijn Bouckaert dan Gerrit De Geest, 'Economics of Public and Tax Law' (2000) 4 Encyclopedia of Law and Economics 
Davood Farhadi Sartangi PKD dan AK, 'Review of The Impact Of Inflation Uncertainty On The Financial Development Of Banking Sector (Case Study: D8)' 6 Astra Salvensis

Yuwita Ariessa Pravasanti, 'Dampak Kebijaksanaan Dan Keberhasilan Tax Amnesty Bagi Perekonomian Indonesia' (2018) 16 Jurnal Ilmiah Akutansi

\section{Internet}

Finansialku.com, 'Bagaimana Kabar Kelanjutan Setelah Amnesti Pajak Yang Sudah Berakhir?' (Finansialku.com, 2017) <https://www.finansialku.com/setelahamnesti-pajak-berakhir-kehadiran-aeoi-automatic-exchange-information-diindonesia/> accessed 10 August 2018

Independent, 'EU Creates Blacklist of 17 Tax Heaven Countries' (Independent, 2017) <https://www.independent.co.uk/news/business/news/eu-tax-havenoffshore-avoidance-countries-blacklist-latest-a8092826.html $>$ accessed 1 April 2019

OECD, 'Convention on Mutual Administrative Assistance in Tax Matters' (OECD, 2019) <http://www.oecd.org/ctp/exchange-of-tax-information/conventionon-mutual-administrative-assistance-in-tax-matters.htm $>$ accessed 18 August 2018

\section{Regulations}

Explanation of Lieu of Law number 1 year 2017 on Acess to Finance Information for Taxation Purposes (The Republic of Indonesia State Gazette Year 2017 Number 95 Annotation 6051).

HOW TO CITE: Adrian Adhitana Tedja, Vincent Arta Wijaya, and Jevelyn Lidyawati, ‘Automatic Exchange of Information on Indonesia Jurisdiction in order to Control Business Opportunities' (2019) Vol. 2 No. 2 Notaire. 
--This page is intentionally left blank-- 